\title{
IMPORTANCE OF GRANTING \\ TO THE CONSTITUTIONAL COURT OF GEORGIA THE AUTHORITY OF CONSIDERING \\ THE “REAL-LIFE” CONSTITUTIONAL APPEALS
}

\begin{abstract}
On the basis of the current legislation in relation to the issues of the second chapter of the Constitution (Human rights), the Constitutional Court of Georgia considers only the issue of the constitutionality of the content of normative acts and considers the appeals as inadmissible where the violation of rights is derived not from the content of the norm but its misuse in practice. This approach extends as well to those cases when the violation of a person's rights is caused by incorrect interpretation of the norm by the court and improper use in the process of legal correlation. The Georgian Legislation does not grant to the Constitutional Court the authority to consider the indicated issue. The indicated issue is a legal problem to the extent that the initial point of the democratic states is to defend the human rights and correspondingly, the primary goal of the constitutional control should be the restoration of the human rights violated by the state structures (authorities). However, the recent precedential law gives us a possibility to make the conclusion that the General Courts in a number of cases define the law contrary to the Constitution, and the Constitutional law is powerless to restore the right of the person whose right was violated by the action of the judge of the court. The aim of this article is to analyze advantages and disadvantages of real-life constitutional appeals and prove importance of granting to the Constitutional Court of Georgia the authority of considering the "realistic" constitutional appeals.
\end{abstract}

* School of Law, Grigol Robakidze University, Georgia, e-mail: ana.kuchukidze@drm.ge 


\section{Key words}

Constitutional court, constitutional submission, Georgia, individual constitutional appeal

\section{Introduction}

In Georgia the judicial authority (judiciary) is wielded through the constitutional control, justice and other forms established by the law. Justice is See above by the General Courts, which include the Georgian Supreme Court, the appellate court and the regional (city) courts. The regional court may as well consist of magistrate judges. And the body of Constitutional Control is the Constitutional Court.

Although conceptually they belong to one branch (of authority), the Georgian General Courts and the Constitutional Court create different systems of legal control. Contact between the Constitutional Court and the General Courts is minimal. In this respect there are available only two points of intersection: 1) Appointment of three judges by the General Court during staffing of the Constitutional Court, and 2) General Courts making a constitutional submission to the Constitutional Court (Menabde, 2010, p. 128). The goal of this article is to demonstrate how important the existence of closer contact between the Constitutional and General Courts is. First of all, it implies equipping the Constitutional Court with the rights of constitutional control of the court decisions of the General Courts, the aim of which is to create mechanisms on the domestic level, which is authorized to rectify the mistakes of the Supreme Court as the mistakes made by the final instance and through it, together with the control of the judicial power, to restore the violated rights of a person (Meskhishvili, 2012, pp. 167-168).

\section{The authority of the Constitutional Court in the sphere of norm control}

On the basis of the current legislation in relation to the matters dealt with in the second Chapter of the Constitution, the Constitutional Court of Georgia considers only the issue of the constitutionality of the content of normative acts and considers the appeals as inadmissible where the violation of rights is derived 
not from the content of the norm but its misuse in practice. In other words, we have to differentiate the legal (normative) reality given in the disputed norm and an actual reality which is a result of its application (Constitutional Court of Georgia, 2006, p. III). The issue of misuse of the norm from the point of view of legality and constitutionality is the sphere of control (Constitutional Court of Georgia, 2008a) and, relatively, lies beyond the powers of the Constitutional Court. This approach extends as well to those cases when the violation of a person's rights is caused by incorrect interpretation of the norm by the court and its improper use in the process of legal correlation. The Georgian Legislation does not grant the Constitutional Court the authority to consider the indicated issue. In the judgment in the case of "Anatoli Kozlovski vs. the Parliament of Georgia" we read that The Constitutional Court is not able to assess the practice of legal usage. Explaining to what extent a given norm has been correctly used or defined by the judge is beyond the scope of competency of the Constitutional Court (Constitutional Court of Georgia, 2008).

The indicated issue is a legal problem to the extent that the cornerstone of the democratic states is to defend the individual's rights and correspondingly, the primary goal of the constitutional control should be the restoration of the person's rights violated by the state structures (authorities) (Kvetenadze, 2013, p. 91). However, the recent precedential law gives us a possibility to make the conclusion that the General Courts, in a number of cases, define the law contrary to the Constitution and the Constitutional law is powerless to restore the right of the person whose right was violated by the action of the judge of the court. For instance, in the case of "The public defender (Ombudsman), the citizen of Georgia Elguja Sabauri and the citizen of Russian Federation Zviad Mania vs. the Parliament of Georgia" (Constitutional Court of Georgia, 2009), the Constitutional Court stated that the problem lies essentially not in the unconstitutionality of the norm but in its incorrect definition by the General Court. Actually, accused the General Courts of non-constitutional action and of being in violation of human's rights, but this had no real-life result (Menabde, 2010, p. 132).

Consequently, questions naturally appear here: to what extent to what extent is the existing constitutional mechanism effective from the point of view of human rights protection? To what extent in reality does the constitutional suit provide restoration of violated rights? (Kvetenadze, 2013, p. 94). Is the mechanism of constitutional submission of the General Courts an effective mechanism to avoid receiving a decision of the General Court based on non-constitutional laws? We think that these questions should be answered first and then we should discuss the issue whether it is really needed and necessary to increase the group 
of constitutional objects and grant to it the right to check the constitutionality of decisions of General Courts.

\section{The Individual Suit}

The individual constitutional suit is a special legal mechanism by means of which the physical and legal persons have a possibility to appeal to the Constitutional Court with the request to cancel the constitutional norm and in this way to defend themselves from the negative effect which they experience as a result of application of this norm. In the given case we consider the individual constitutional suit only with regard to as to what extent it protects the person from the non-constitutional decisions of the General Courts.

Until the changes in the Georgian law of February 12, 2002 "On the Constitutional legal proceedings" the Article 39 of Organic Law of the Georgian Constitutional Law used to grant to the physical and legal persons the rights to submit the constitutional suit to the Constitutional Court only if they considered that the rights and freedoms acknowledged in the Second Chapter of the Georgian Constitution had been violated. Correspondingly, that version of the norm did not give a possibility to individuals to argue about the constitutionality of the norm until their rights were violated, i.e. until the General Court made a decision based on an unconstitutional norm. This, actually, made the individual constitutional suit invalid as a mechanism for defending the persons from non-constitutional actions of the General Courts.

The situation was relatively improved by the changes from 12 February 2012 when it was defined that physical and legal persons have the right to submit the suit if they think that their rights have been violated and it is possible to violate directly the rights and freedoms acknowledged by the Second Chapter of the Georgian Constitution. Relatively, according to the current legislation, the physical and legal persons were given the possibility to appeal to the Constitutional Court when their rights have not yet been violated but there is a real threat of their violation, for instance, a threat that in the case where they are the parties the General Court will issue a decision on the basis of a non-constitutional norm. However, even this change cannot completely ensure the protection of rights and freedoms of the persons guaranteed by the Constitution just as the submission of individual suit to the General Court does not prevent discussion of the case at the General Court.

Accordingly, it is clear that if the Constitutional Court acknowledges the norm as non-constitutional before receiving the decision by the General Court, 
the argued act loses its power and the judge of the General Court will not be able to use it. However, if - before receiving the decision of the Constitutional Court - the General Court had have time to issue a decision that the $20^{\text {th }}$ Article of the Georgian Law "On the Georgian Constitutional Court" will be activated according to which according to which acknowledgement of the law or another normative act as non-constitutional does not mean cancelling the judgements and decisions made early on the basis of this act, if it causes only prevention of their execution according to the rule established by the procedural legislation. As it is shown even in the case if the lawsuit request is satisfied by the Constitutional Court, the plaintiff's right - which was violated by the General Court on the basis of the General Court using a non-constitutional law - will not be restored. The Constitutional Court has no possibility to control the General Courts; the Court will cancel the normative act but "will wash their hands of the matter," i.e. avoid reviewing the decisions made on the basis of these acts. The legislation does not give a possibility to reconsider the decisions of the General Court (Zoidze, 2007, p. 187).

The indicated issues are the subjects of discussion at the Constitutional Court even today which confirms once more their topicality and importance.

In November 2015 and February 2016, the Broadcasting Company "R-2" and the company "Saqartvelo" Ltd, appealed to the Constitutional Court with the Constitutional appeal (N 678 and N 719).

The Constitutional appeal N 678 put under discussion the constitutionality of the normative content of the first part of Article 423 of the Georgian Civil Procedure Code which excludes the possibility - if new circumstances appear in civil justice cases - to appeal the decision being in lawful force with the request of request to reopen the case proceedings, if there is already a decision of the Constitutional Court by which the Constitutional Court acknowledged the normative act on which the GC had based the decision. The plaintiff thinks that the renewal of case proceedings because of newly discovered circumstances is the kindness of being protected by the right to fair trial ensured by the first paragraph of Article 42 of the Georgian Constitution (Constitutional Court of Georgia, n/d).

In the Constitutional Appeal registered under the number 719, the plaintiff considers that the disputed norm which declares that the acknowledgement of the Law or other normative act as non-constitutional does not mean that the verdicts and decisions decreed early on the basis of this act are invalid, causes only suspension of their fulfillment under the rule established by the procedural legislation, contradicts the first paragraph of the Georgian Constitution and 
other constitutional provisions. The acknowledgment of the normative act as non-constitutional by the Constitutional Court should be followed by effective legal results.

If during wielding of justice the court is guided by a legislative norm which is acknowledged by decision of the Georgian Constitutional Court, the legal result of acknowledgement as a nonconstitutional naturally should be the cancellation of the relative court act. Otherwise, acknowledgement of the normative act as a non-constitutional by the Georgian Constitutional Court will be only of declarative character (Constitutional Court of Georgia, $\mathrm{n} / \mathrm{d}$ ).

As we see, the plaintiffs try to prove that the right to control the decisions of the General Courts is in the hands of the Constitutional Court or that it is possible to have within the frame of an individual constitutional appeal, which means that the satisfaction of individual appeal should result in the revision of those decisions of the General Courts which were based on the norm acknowledged as a nonconstitutional.

In spite of the fact that the Constitutional Court has yet not issued a decision on the mentioned cases, it is hardly supposed that it shares the position of the parties since as Aleksandre Pirtskhalaishvili indicates in his conclusion: On the basis of Paragraph 5 of Article 84 and the systematic analysis of Article 89 it should be told that the Constitutional Court does not possess the explicit and implicit to recheck the acts of their General Courts. As follows from the essence of the principle of the legal state, none of the bodies of the governmental authorities, including the Constitutional Court, has any "competence of graining the competence" without distinctly expressed will of the Constitution (Phirtskhalashvili, $\mathrm{n} / \mathrm{d}, \mathrm{p}$. 16). Revealing of such a will is only the authority of the Constitution and not of the Constitutional Court (Phirtskhalashvili, n/d, p. 15).

Considering the above -within the frame of the current constitution and legislation we cannot deem the individual suit as an effective and perfect mechanism of defending of human rights and freedoms.

This has been indicated as well by the European Court of Human Rights, in particular in the case "Apostle vs. Georgia", where in the decision we read: "The Constitutional proceeding court of Georgia differs, for instance, from the German, Spanish, and Czech practice. In these countries there are 'the specific' constitutional means of appeal (address), which give to the constitutional courts a possibility to improve the violations of rights by the officials or when the violation of rights guaranteed by the Constitution is the result not of the decision, but of other kind of interference to prohibit the due ministry to continue the violation of indicated right and show (direct) him if it is possible to restore the 
state before violation - statu quo ante (...) In comparison to the above-indicated, the Georgian Constitutional Court is not authorized to cancel those individual decisions issued by the public agencies or the courts influence directly on the plaintiff's rights (...) In addition to this, the court notes that the Article 89 ( 1 "v") of the Constitution allows the individuals to appeal with the so called 'abstract' suit (...) Instead, they have no possibility to appeal the decisions received by the courts or the public agencies which directly influence on their personal state" (Zaalishvili, n/d).

The European Court has compared the constitutional means of the abovementioned appeal with the means of appeal to the constitutional Court of Hungary which had been deemed as inefficient for the purposes of the Article 35 of the Convention as the Supreme Court of Hungary is limited only by the abstract control by the state relative to the private persons without the possibility of cancelling or change of spent (arranged) individual events. (Supreme Court, 2007).

With a view to all the above, I think it is clear that an individual suit from the definite point of view is effective in case of the threat of violation of rights of a person guaranteed by the constitution, though unambiguously it is not an effective means (Kvetenadze, 2013, p. 94).

\section{The constitutional submission of the General Courts}

In spite of the fact that the constitutional control is exercised by a specially formed body - the Georgian Constitutional Court - the General Jurisdiction Courts actively participate in this control as well; according to the current legislation, the General Courts are not able to exercise directly the constitutional control though they have the right to appeal to the Constitutional Court through the constitutional submission and argue about the compliance of the normative act with the Constitution (Urushadze, 2013, p. 114). This authority gives a possibility to the General Courts to avoid reaching a decision on the basis of the unconstitutional norm. However, it is a fact that the General Courts exercise these rights very seldom. This is perceived unambiguously negatively by the jurists.

As an example, we can bring the specific assessments. T. Urushadze: "It might be said that the institute of the constitutional submission of General Courts to the Constitutional Court has been functioning ineffectively for years (...) And all this, of course, reflects negatively on the judiciary efficiency" (Urushadze, 2013, p. 118). Nino Kvetenadze: “T mechanism of constitutional submission of 
the General Courts is nearly non-functional" (Constitutional Court of Georgia, 2015, p. 97). Badri Kochlamazashvili: "For today in most countries the General Court is authorized to address the Body of Constitutional Control with the submission if it deems that the law or the sub-legislative act which they have to use contradicts the Constitution, but in practice it occurs rarely which is clearly inadmissible" (Kochlamazashvili, 2010, p. 129) Statistics clearly reflect this problem. In the years 1996-2015, there were only 25 Constitutional submissions of General Courts. At the same time, it should be noted that in nine years between 2005 and 2013, the courts did not file any constitutional submissions (see Fig. 1).

As we see, the General Courts definitely are wary of addressing the Constitutional Courts with request to acknowledge a norm as unconstitutional.

\section{Figure 1.}

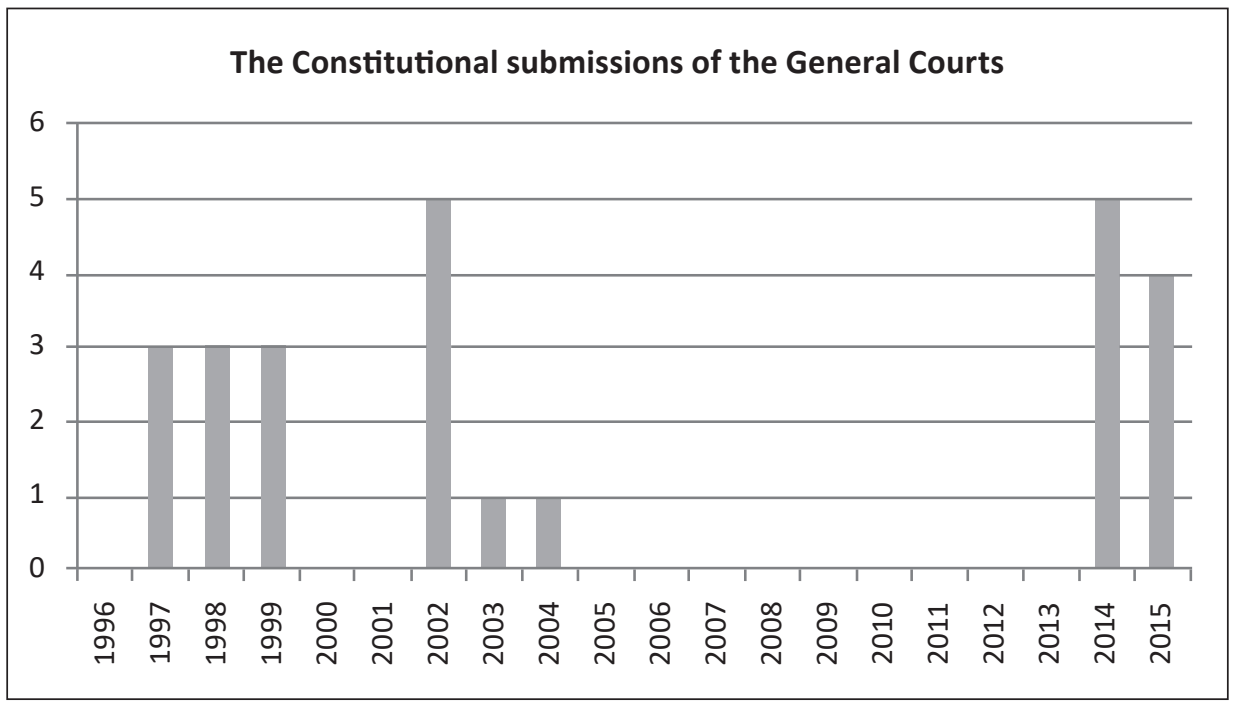

Source: The graph appears on the official website www.constcourt.ge and is based on statistical data.

Considering all the matters indicated above, we conclude that both the individual judgment and the constitutional presentation does not provide perfect protection of human rights. That is why it is necessary that the General Courts should be given the authority to assess the constitutionality of decisions of the General Courts. 


\section{The right of Constitutional Control of decisions of the General Courts}

With the aim to provide legal protection of the constitution, to ensure uniform understanding of its principles and norms, and consequently to have them uniformly applied in practice (Kochlamazashvili, 2010, p. 115), in many countries the constitutional court is equipped with the right to check the constitutionality of decisions of the General Courts. It should be indicated that such control of the General Courts by the Constitutional Court does not mean reviewing the decisions of the General Courts according to their expediency and correctness (Qaldani \& Chkheidze, 2000, p. 217) which causes the transformation of the Constitutional Court into a higher instanc and violation of the principle of finality (Zaalishvili, n/d). Granting this function to the Constitutional Court of Georgia would be ascertainment of only the fact to what extent the receiving of the decision corresponds to the level correspondents to accept the decision to the requirements of the norms of the Constitution (Kochlamazashvili, 2010).

Only three countries of the post-Soviet area are equipped with the right to control the decisions of the General Courts: Azerbaijan, the Republic of Belarus and Tajikistan (Constitution of Azerbaijan, Article 130, Paragraph 4; Constitution of the Republic of Belarus, Article 116; Constitution of Tajikistan, Article 89) (Meskhishvili, 2012, p. 167). Among the European countries the constitutional control systems of Spain and Germany are interesting in this aspect. The Constitutional Court of the Kingdom of Spain is an acting institution which controls the protection of the Constitution first and foremost from the party of state structures including also the courts. The Spain Constitutional Court on the basis of an individual suit (petition) from physical and legal persons does not only affect the abstract definition of constitutional norms. On the contrary, in case of ascertain by its decision it is directed to restoration and compensation of violated right (Kvetenadze, 2013, p. 96).

At the Constitutional Court of Spain, the claims of the citizens are considered in accordance with the procedure following the of the so called amparo rule. As a result of the case considered in accordance with the amparo rule, the decision made by the constitutional court is of individual character and covers only the plaintiffs. An amparo action is used only by the public services of the administration bodies of the courts towards the received acts. The amparo procedure cannot be used towards the laws (Zaalishvili, $\mathrm{n} / \mathrm{d}$ ).

The Constitutional Court of the Federal Republic of Germany is a classic example of an analogous system of constitutional control (Menabde, 2010, p. 144). 
A suit (an appeal) can be submitted to the German Constitutional Court by any person who considers that its main right has been violated by the party of the state organs, including any decision (act) of the court (Khubua \& Trauti, 2001, p. 25). The submitted constitutional claim about decisions of the court causes reviewing the case not in its full volume but only its verification from the point of view of legal violations (Zaalishvili, $\mathrm{n} / \mathrm{d}$ ).

While satisfying the constitutional appeal submitted on a decision of a Court, the Federal Constitutional Court cancels the indicated solution. (...) cancels the indicated solution and returns the case to the competent court for repeated consideration. If satisfaction of the constitutional appeal has happened because of the fact that the appealed decision is based on a non-constitutional law, the indicated law should be declared as invalid (Zaalishvili, n/d).

It is important that the European Court of Human Rights frequently recognizes the Constitutional Court of Germany from the point of view of defending human rights as the mechanism having the most effective intra-legal structures (Kvetenadze, 2013, p. 96).

As for Georgia, according to our Legislation the Constitutional Court has no authority to check the constitutionality of decisions of the General Courts. At the initial stage of writing the law, that function was supposed to be fulfilled by the Constitutional Commission. By the words of the secretary of the Constitutional Commission, later the chairman of the Constitutional Court, Avtandil Demetrashvili, during solution of the issue they invited from Germany professor Helmut Steinberger who gave his definite recommendations to the Georgian legislators. All his considerations were actually considered except that the constitutional court should be given the right to check the constitutionality of the decisions of the General Court (Chkheidze, 1999).

Later, in the year 2004, on the initiative of the president a Project of the Constitutional Law of Georgia was submitted to the Parliament of Georgia. According to the project, the $5^{\text {th }}$ Prima Chapter "The Constitutional Control” should be added to the Constitution. Because of unrefined details too many opponents appeared against it. Ultimately, this part of legislation did not become a part of the Constitution and the provisions which concern the constitutional court in this aspect still correspond to the first edition.

I think that it is necessary to continue to work on this topic with the aim to defend human rights and freedoms, and to equip the Constitutional Court with the authorization to have constitutional control over the General Courts. This will promote the transformation of the main rights freedoms of a human being and into actual judiciary solutions, will raise the rank of decisions of the General 
Court, raise the level of mutual contact and cooperation between the system of General Courts and the Constitutional Court, establish the united practice of defining the constitutional rights and freedom of a person and, finally, what is most important, increase the confidence (trust) of the population in the court system (Sharashidze, 2010, p. 217).

In turn, equipping the Constitutional Court with the right to control the decisions of the General Courts can be deemed as one of the strong levers for promotion of constitutional submission of the General Courts. On the basis of the rights to control the General Courts, a kind of "competition" may be established between the General Courts and the Constitutional Court, which may increase the rank and responsibility of the decisions of the General Court (Meskhishvili, 2012, p. 168). Such a conclusion can be justified not only by pure theoretic discussion but by specific examples from the practice of the Georgian Court as well.

Example 1. A citizen of Georgia T. Bejhitashvili on the issue of illegal dismissal from the post tried to restore the violated right in the court. By decision of the Court of Appeal of Tbilisi of 26 September 2013 No 3B/1033-13626, the order No. 502 of his dismissal was considered as illegal and the obligation to compensate the balance for the missed period was imposed on the defendant. The plaintiff appealed against the indicated solution of the Tbilisi Court of Appeal at the Supreme Court and requested compensation for the missed period not in quantity of 3-month remuneration but the compensation in full volume, though the cassation complaint has been acknowledged as inadmissible (Constitutional Court of Georgia, 2015). With the aim to check the constitutionality of the normative act applicable in the given case, neither the Tbilisi Court of Appeal nor the Court of Cassation has submitted the constitutional presentation to the Georgian Constitutional Court. Later, on 24 February 2014 T. Bejhitashvili herself turned to the Constitutional Court with appeal in which she requested that the second sentence of Article 112 of the Georgian Law "About the Public Law" were acknowledged as an unconstitutional. During the same period a similar case was considered again by Tbilisi Court of Appeal. However, this time in contrast to the previous case, the Tbilisi Court of Appeal on 30 April 2015 suspended the proceeding of the case in relation to considering the appeal complaint of Maia Rukhadze and appealed with the constitutional submission to the Georgian Constitutional Court (Constitutional Court of Georgia, 2015a). 
Example 2. On 11 February 2014 a citizen of Georgia, Giorgi Ugulava addressed the Georgian Constitutional Court with a constitutional appeal (registration No. 574) and requested to acknowledge as unconstitutional Article 159 of the GCC (Georgian Criminal Code) and the second sentence of the first part of Article 160 of the same Code on the basis of which his dismissal from the post had been affected (Constitutional Court of Georgia, 2014).

On 1 April 2014 Batumi City Court (Judge David Mamiseishvili) addressed the Georgian Constitutional Court with a constitutional submission (registration No. 583) and requested to consider the case of non-constitutionality of Article 159 of the Georgian Criminal Code (GCC).

We think that the above-indicated cases are clear examples of the fact that the activity of the citizens has become a kind of stimulus for the judges of the General Courts to address the Constitutional Court by presenting a onstitutional submission. Consequently, we can confirm that equipping the citizens with the right to control the constitutionality of decisions of the General Courts will significantly increase the concurrence (competition) and - as we have already indicated - the judges of the General Courts will have more motivation and interest directly during the consideration of a specific case itself and during a party's address to the Constitutional Court with the relative presentation.

With regard to all this, I think that in case of increase of the scope of interest, the General Courts will apply the constitutional mechanism of submission though it does not mean that for the main purpose of introduction the giving a stimulus to the General Courts should be thought This is only a positive effect and not the purpose. The purpose of introducing such a system is only one - to secure protection of human rights, as an everlasting and supreme value.

In addition to the above listed positive sides, causes are available as well which make the efficiency of this system doubtful, which is the subject of definite dispute. In opinion of a certain circle, granting the Constitutional Court the authority to control the decisions of the General Courts on the one hand contradicts the constitutional principle of non-interference in the judicial power and on the other hand, imposition of indicated authorization will cause overloading of the Constitutional Court (Kvetenadze, 2013, p. 93). As for the first argument, I consider that in case of refined legislation, we shall avoid the competence incompatibility between the General Courts and the Constitutional Court. And as for the issue of overloading, it the opinion of Vakhtang Menabde is interesting. He considers that the possible overloading of the Constitutional Court still remains the main argument against introducing the system of constitutional control of the activity of the General Courts, especially as with their current 
authority, the Constitutional Court is not known for the speed of its proceedings. The practice of the last years has confirmed that the Constitutional Court needs nearly two years to declare the final decision on the case. This is based on the data for 2007, 2008 and 2009, when, only 34, 26 and 17 suits had been submitted to the Constitutional Court (Menabde, 2010, p. 139). Vakhtang Menabde considers as well that the overloading of the Constitutional Court in addition to promptness of decreeing the solutions might negatively influence also the quality of the decisions. To solve this problem, the conclusion of the Venice Commission from 14 March 2005, suggested increasing the number of the members of the Constitutional Court from 9 to 15 and establishing 5 chambers at the Court (Sharashidze, 2010, p. 216). There are more means available to avoid case overload, in particular:

\section{Establishment of request for exhaustion of all intrastate means before} the lawsuit was submitted to the Constitutional Court. For example, in accordance with the German model, "Appeal to the Federal Constitutional Court is admitted only in case if the person who considers that his main rights have been violated exhausted all possible legal forms and appealed to all those instances which are obliged to defend his main right. (...) The constitutional complaint should be appealed to the Federal Constitutional Court after receiving of the decision of the final Instance Court" (Zaalishvili, $\mathrm{n} / \mathrm{d}$ ). Here it is interesting Another authority which has the Federal Constitutional Court. In particular: The second part of the Paragraph 90 of the Law "On the Federal Constitutional Court" admits as an exception the possibility to receive a decision about the constitutional complaint when all legal forms have not been yet exhausted, if it is of universal importance, or the applicant can be significantly damaged (Zaalishvili, $\mathrm{n} / \mathrm{d}$ ). I think that it is possible that the Georgian Constitutional Court should be equipped as well with the likewise authorization as the indicated one directly serves the aim of defending the constitutional justice.

\section{Definition of a reasonable period for appealing against decision of the} General Court. For example, by the Law of Germany the constitutional complaint should be appealed and substantiated within the period of a month. The date is counted from the day that any form of the complete text of a decision is issued (Zaalishvili, $\mathrm{n} / \mathrm{d}$ ). In relation to terms it should be underlined that only the legal limitation should be defined there. I cannot agree with the opinion that it is necessary to write down the reasonable date by which the constitutional court will finalize the consideration of the case. Such an approach will directly contradict the policy of the Constitutional Court which it drew up in the decision 
N3/2/577 on the basis of which Paragraph 4 of Article 22 of the Georgian Law on the Constitutional Law was declared invalid and which stated that in case if the term of consideration of the case is unreasonably long, protection of the rights will be delayed and will lose its efficiency. And if an unreasonably short date is set, the parties and the Court are deprived of the possibility to represent to the court the evidence important for the case, to investigate perfectly the circumstances of the case and complete the necessary procedural actions, which will negatively reflect on the quality of consideration of the case, threaten the safety of those constitutional rights and freedoms for protection of which a person appeals to the Court, pose the threat of receiving a non-substantiated decision and, correspondingly, cause the encroachment of the right to a fair trial. Relatively, providing prompt justice at the expense of limiting the right to receive a substantiated decision is unjustified. The right of appeal to the Constitutional Court should not be illusive but it should create the real possibility of due restoration of the rights of a person and should represent an effective means to defend that right (Constitutional Court of Georgia, 2014a).

In this very case the Court declared that the Constitutional Court does not exclude the authority of the legislator to ascertain the terms of completion of separate procedural actions though any limitation should also be a means of achieving a worthy public purpose (Constitutional Court of Georgia, 2014a). From the given discussion it is clear that the Constitutional Court considers it admissible to ascertain the reasonable term for consideration of the case, but it should not happen at the increased expense of human rights (Constitutional Court of Georgia, 2012). We think that in the given case there are no grounds to suppose that the appeals submitted with regard to the issue of control of decisions of the General Courts are characterized by lesser complexity or should be studied less deeply. Simultaneously, it is not clear what important public aim would make it necessary to introduce such strict measures as ascertainment of limited imperative terms for consideration of the constitutional appeal of this type. Thus, I think that to avoid overloading of the Constitutional Court it is possible to introduce specific terms for submissions cases for judgment by the Constitutional Court.

3. The abuse of the right to appeal to the Constitutional Court should be punishable like in the German model. Proceedings at the Federal Constitutional Court are free of charge, though a State Fee can be imposed on the appealing person to the amount of 5000 German Marks if he abuses the right to submit it for the constitutional appeal (Zaalishvili, $\mathrm{n} / \mathrm{d}$ ). 
I think that considering these recommendations will significantly reduce the expected negative effect and the possibility of reviewing of decisions of the General Court by the Constitutional Court will be established as an effective mechanism of protection the human rights.

\section{Conclusion}

Analysis of the scope of authority of the Constitutional Court and the existing practice make it clear that the individual constitutional appeal and a constitutional submission of the General Courts is not a sufficiently effective mechanism for protecting human rights, and it is desirable that the Constitutional Court were equipped with the right to control the decisions of the General Courts. It is possible to develop legislative levers of various kinds to minimize existing risks and threats that could emerge during introduction of such a system, which ultimately leads to the conclusion that the Constitutional Court of Georgia will have a real possibility to duly restore the rights of a person (Constitutional Court of Georgia, 2014a).

\section{REFERENCES}

Supreme Court. (2007). Georgia. November 28, 2006, N40765/02. Retrieved from http:// www.supremecourt.ge/files/upload-file/pdf/apostoli.pdf

Zaalishvili, N. (n/d). The international practice of the Constitutional Control of decisions of the General Courts and perspectives of its establishment in Georgia. Retrieved from http://www.parliament.ge/files/legal_issues/publications/saerto_sasamartloebi.pdf

Zoidze, B. (2007). The Constitutional Control and the order of values in Georgia. Tbilisi. Kvetenadze, N. (2013). The Constitutional Control of decisions of the General Courts - the effective mechanism of defense of the Human's rights. The Students' Legal Journal, 90-98.

Kochlamazashvili, B. (2010). Legal Protection of the Constitution. Bona Kauz.

Menabde, V. (2010). A paradigm of specific control in the constitutionalism. The Constitutional and International Mechanisms for Defense of Human Rights. 123-147.

Meskhishvili, Q. (2012). Appeal to the Constitutional Court as a constitutional legal means for defense of rights. The modern Constitutional Justice. 147-169.

Constitutional Court of Georgia. (n/d). Retrieved from http://constcourt.ge/ge/legalacts/statistics

Constitutional Court of Georgia. (2006). Decision N1/1/357 of the Georgian Constitutional Court of 31 May 2006, in the case "The citizens of Georgia Tamaz Kilanava, 
Nugzar Kandelaki, Manana Nasaridze, Madona Ghibradze and Lali Archvadze vs. the Parliament of Georgia".

Constitutional Court of Georgia. (2008). Judgment N1/2/440 from 4 April 2008 in the case "Anatoli Kozlovski vs. the Parliament of Georgia".

Constitutional Court of Georgia. (2008a). Judgment of the Georgian Constitutional Court of 4 December 2008 in the case "The citizen of Georgia Akaki Mikadze vs. the City Council of Tbilisi".

Constitutional Court of Georgia. (2009). Decision N1/1/428,447,459 of the Georgian Constitutional Court of 13 May 2009, in the case "The Public Defender, citizen of Georgia Elguja Sabauri and the citizen of Russian Federation Zviad Mania vs. the Parliament of Georgia".

Constitutional Court of Georgia. (2012). Decision N 3/1/512 of the Georgian Constitutional Court of 26 June 2012, in the case "The citizen of Denmark Heike Cromqvist vs. the Parliament of Georgia".

Constitutional Court of Georgia. (2014). Decision of the Georgian Constitutional Court in the case N 3/1/574 "Citizen of Georgia, Giorgi Ugulava vs. the Parliament of Georgia".

Constitutional Court of Georgia. (2014a). Decision of the Georgian Constitutional Court, from 24 December 2014 in the case N 577: "The citizen of Georgia Vakhushti Menabde vs. the member of the Parliament of Georgia".

Constitutional Court of Georgia. (2015). Decision of the Georgian Constitutional Court of 31 July 2015, N 2/3/630 in the case: "The citizen of Georgia Tina Bejhitashvili vs. the Parliament of Georgia".

Constitutional Court of Georgia. (2015a). Judgment of the Georgian Constitutional Court of 25 November 2015 for the constitutial submission of Tbilisi Appellation Court on the comstitutionality of the second sentence of Article 112 of the Georgian Law "On Public Service".

Urushadze, T. (2013). The problematic issues connected with the constitutional submission to the General Court. Student's Legal Journal. 113-119.

Sharashidze, M. (2010). Perspectives of granting to the Constitutional Court of Georgia the authority of considering the real-life constitutional appeals, the constitutional and international mechanisms of the defence of human rights. 209-218.

Chkheidze, G. (1999). The problems of constitutional control in Georgia. Retrieved from http://www.nplg.gov.ge/gsdl/cgi-bin/library.exe

Khubua, G., \& Trauti, I. (2001). The constitutional justice in Germany. Tbilisi: GTZ.

Qaldani, T., \& Chkheidze, G. (2000). The reality of the Constitutional Court of Georgia and perspectives of development.

Phirtskhalashvili, A. (n/d). Expert Conclusion about the case N 678, 719. On the cases of the first part of Article 423 of the Code of Civil Proceedings of Georgia "About the constitutional Court" of organic law the Article 20 and the first and $10^{\text {th }}$ paragraphs $10^{\text {th }}$. 